Jurnal Dinamika Ekonomi Syariah

Vol 08, No. 01, 2021, hlm.1

http://ejurnal.iaipd-nganjuk.ac.id/index.php/es/index

ISSN-e 2715-7334 | ISSN-P 2654-3567

\title{
Dampak Pandemi Covid-19 Terhadap Perekonomian Dalam Tinjauan Sektor Perdagangan Dan Pariwisata Kabupaten Nganjuk (Deskriptif Analisis Sektor Perdagangan)
}

\author{
Dewi Fitrotus Sa'diyah ${ }^{1}$, Muklas Ary Sona ${ }^{2}$, Diah Ismaya ${ }^{3}$ \\ ${ }^{1}$ Institut Agama Islam Pangeran Diponegoro Nganjuk. Jl.Wilis Kramat,Nganjuk \\ ${ }^{2}$ Institut Agama Islam Pangeran Diponegoro Nganjuk. Jl.Wilis Kramat,Nganjuk \\ 3Institut Agama Islam Pangeran Diponegoro Nganjuk. Jl.Wilis Kramat,Nganjuk \\ E-mail: dewisakhi03@gmail.com,muklas.sona18@gmail.com
}

\begin{abstract}
:
At the end of 2019, the world was shocked by Covid-19 from China. Not only causing casualties but also having an impact on the national economy, including in Nganjuk Regency. To restore economic stability, the Nganjuk Regency Government took steps in implementing the new normal so that the community remained productive and maintained economic stability. The problem raised in this study is the economic growth of the people of Nganjuk district before and during the Covid-19 Pandemic and its impact on employment opportunities and household income of the Nganjuk community. The purpose of this study is to see the economic growth of the Nganjuk community before and during the Covid-19 Pandemic and its impact on employment opportunities and household income of the Nganjuk community. The type of research used in this research is descriptive research with a qualitative approach. The results show that the economic growth of the Nganjuk Regency community before the Covid-19 outbreak was felt to be stable, this can be seen from the income of traders which tends to increase. During the period past the Covid-19 pandemic, the community had a significant economic impact, this was felt by many traders who experienced a decrease in turnover of around 75\%. And based on the central statistical agency, the number of unemployed people in 2019 has increased by 3 thousand people. To respond to the impact of the Covid-19 pandemic.
\end{abstract}

Keywords: Covid-19 Pandemic, Economy, Trade Sector, Tourism

Abstract:

Akhir tahun 2019, dunia dihebohkan dengan Covid-19 dari China. Bukan hanya menimbulkan korban jiwa saja tetapi juga berdampak pada perekonomian secara nasional, termasuk di Kabupaten Nganjuk. Untuk mengembalikan stabilitas perekonomian, Pemerintah Kabupaten Nganjuk mengambil langkah dalam penerapan new normal agar masyarakat tetap produktif serta terjaga stabilitas perekonomian nya. Masalah yang diangkat dalam penelitian ini adalah pertumbuhan perekonomian masyarakat kabupaten Nganjuk sebelum dan dalam masa Pandemi covid-19 serta dampaknya terhadap kesempatan kerja dan pendapatan rumah tangga masyarakat Nganjuk. Tujuan penelitian ini adalah untuk mengetahui pertumbuhan perekonomian masyarakat Nganjuk sebelum dan dalam masa Pandemi covid19 serta mengetahui dampaknya terhadap kesempatan kerja dan pendapatan rumah tangga masyarakat Nganjuk. Jenis Penelitian yang digunakan dalam penelitian ini adalah penelitian deskriptif dengan pendekatan kualitatif, Hasil Penelitian menunjukkan bahwa pertumbuhan perekonomian masyarakat kabupaten nganjuk sebelum wabah covid-19 dirasakan stabil, hal ini dilihat dari pendapatan para pedagang yang cenderung meningkat. Dalam masa melewati pandemi covid-19 masyarakat nganjuk mengalami dampak perekonomian yang signifikan, hal ini dirasakan oleh banyaknya pedagang yang mengalami penurunan omset sekitar $75 \%$. Dan berdasarkan badan pusat statistik Jumlah penganggur tahun 2019 bertambah 3 ribu jiwa, Untuk menyikapi adanya dampak pandemi covid-19 Berdasarkan data sebanyak 41.141 kepala keluarga di Kabupaten Nganjuk akan mendapatkan dana bantuan jaring pengaman sosial dampak Covid-19 dari Pemerintah Pusat dan Pemprov Jatim.

Keywords : Pandemi Covid-19, Perekonomian, Sektor Perdagangan, Pariwisata. 


\section{PENDAHULUAN}

Sejak akhir tahun 2019, dunia dihebohkan dengan adanya wabah virus corona yang berasal dari China. Virus corona menyebabkan kepanikan di China dan menimbulkan korban jiwa sampai ribuan orang penduduk China. Akibat lainnya, banyak perusahaan kecil, menengah maupun besar yang akhirnya terpaksa menutup usahanya untuk sementara. Tidak hanya perusahaan saja yang tutup, ribuan tempat usaha makanan/ minuman juga terpaksa tutup. Perekonomian China pun menjadi terguncang di awal tahun 2020 ini, karena selama ini perekonomian China didukung dari sektor usaha kecil dan menengah. Ada sekitar 30 juta usaha kecil dan menengah menyumbang lebih dari $60 \%$ dari Produk Domestik Bruto (PDB) China. Selain itu, bursa saham Shanghai juga sempat menurun mencapai 9\%, yang merupakan yang terparah sejak bulan Agustus 2015. ${ }^{1}$

Dengan melihat kondisi perekonomian China saat ini banyak analis yang memprediksi pertumbuhan ekonomi China dapat turun mendekati angka 5\% di tahun 2020. Industri yang paling terkena dampaknya adalah industri manufaktur dan pariwisata. Seperti kita ketahui, Kota Wuhan di mana tempat awal mula wabah virus corona terjadi, merupakan pusat industri otomotif di China. Kontribusi Kota Wuhan terhadap perekonomian China mencapai 1,6\%. ${ }^{2}$

WHO (World Health Organization) telah menetapkan status gawat darurat global untuk wabah virus corona. Dunia menjadi waspada akan wabah virus ini. Tidak hanya waspada terhadap penyebaran penyakitnya saja akan tetapi juga waspada terhadap dampak yang mungkin terjadi terhadap perekonomian dunia. Menurut Direktur Pelaksana IMF, Kristalina Georgieva, dengan adanya wabah virus corona, diperkirakan dalam jangka pendek akan terjadi perlambatan ekonomi global. ${ }^{3}$

Wabah virus corona di China juga diduga berdampak pada perdagangan pertanian Indonesia. Selama ini ekspor minyak kelapa sawit merupakan salah satu kontributor ekspor terbesar ke China. Namun bulan Februari 2020, realisasinya hanya mencapai 84.000 ton. Angka ini sangat jauh jika dibandingkan dengan realisasi di bulan sebelumnya yaitu Januari 2020 sebesar 487.000 ton dan pada periode yang sama tahun 2019 yang mencapai 371.000 ton. Dari sisi impor pangan, Indonesia yang memiliki ketergantungan bawang putih dari China, hanya dapat mengimpor bawang putih dari China sebesar 23.000 ton pada Februari 2020. Angka ini juga turun drastis jika dibandingkan dengan impor tahun sebelumnya yang mencapai 583.000 ton. ${ }^{4}$ Sebagai pangsa ekspor China, Indonesia turut terkena dampak yang kemudian berpengaruh pada neraca perdagangan Indonesia, Selain itu dampak Wabah Virus Corona juga berpengaruh terhadap Sektor Pariwisata.

Data Badan Pusat Statistik (BPS) menunjukkan bahwa wisatawan asal China mencapai 2.07 juta orang pada tahun 2019 yang mencakup 12.8 persen dari total wisatawan asing sepanjang 2019. Penyebaran virus Corona menyebabkan wisatawan yang berkunjung ke Indonesia akan berkurang. Sektor-sektor penunjang pariwisata seperti hotel, restoran maupun pengusaha retail pun juga akan terpengaruh dengan adanya virus Corona. Okupansi hotel mengalami penurunan sampai 40 persen yang berdampak pada kelangsungan bisnis hotel. Sepi nya wisatawan juga berdampak pada restoran atau rumah makan yang sebagian besar konsumennya adalah para wisatawan. Penyebaran virus Corona juga berdampak pada sektor usaha mikro, kecil dan menengah (UMKM) karena para wisatawan yang datang ke suatu destinasi biasanya akan membeli oleh-oleh. Jika wisatawan yang berkunjung berkurang, maka omset UMKM juga akan menurun. Berdasarkan data Bank Indonesia, pada tahun 2016 sektor UMKM mendominasi unit bisnis di Indonesia dan jenis usaha mikro banyak

\footnotetext{
1 "Porak-poranda Ekonomi China Akibat Wabah Virus Corona, Banyak Usaha Terancam Bangkrut", 18 Februari 2020, https://www.merdeka.com/ uang/porak-poranda-ekonomi-china-akibat-wabah-corona-banyak-usaha-terancam-bangkrut. html, diakses 12 April 2020

2 "Dampak Virus Corona, S\&P Pangkas Proyeksi Pertumbuhan Ekonomi Tiongkok", 7 Februari 2020, https://katadata.co.id/ berita/2020/02/07/dampak-virus-corona-sp-pangkas-proyeksi-pertumbuhan-ekonomi-tiongkok, diakses 13 april 2020.

3 "Virus Corona Tekan Ekonomi Tiongkok, Dunia Waspadai Perlambatan Global", 5 Februari 2020, https://katadata.co.id/ telaah/2020/02/05/virus-corona-tekan-ekonomi-tiongkok-dunia-waspadai-perlambatan-global, diakses 13 April 2020

4"'Di Depan DPR, Mentan Ngeluh Ekspor-Impor Pangan Terganggu Corona", 17 Februari 2020, https://finance.detik.com/berita-ekonomibisnis/d-4902563/ di-depan-dpr-mentan-ngeluh-ekspor-impor-pangan-terganggu-corona, diakses 13 April 2020
} 
menyerap tenaga kerja. Dan dengan adanya dampak virus corona ini maka akan mengganggu kesempatan kerja dan pendapatan rumah tangga para tenaga kerja.

Provinsi Jawa Timur juga termasuk provinsi yang terkena dampak covid-19. Persebaran Virus Corona Covid-19 di Jawa Timur (Jatim) ikut mempengaruhi gerak perekonomian wilayah tersebut. Perekonomian provinsi ini didominasi sektor perindustrian, dan hampir 20 persen adalah perdagangan.

"Memang pertanian primer mancakup kurang lebih 11 persen ekonomi, dan employnent-nya sekitar 32 persen. Jadi banyak penduduk yang bekerja di sektor non pertanian. Inilah sebabnya kami melakukan beberpa hal strategis untuk menjaga dan memitigasi penyebaran covid-19," ujar Wakil Gubernur Jawa Timur, Emil Dardak, Jumat (3/4/2020).

Pemprov melakukan survei terhadap 100 pabrik terbesar di Jawa Timur dengan total 55 ribu pekerja. "Dari sampling itu kita menemukan bahwa hampir semuanya telah melakukan mitigasi covid19. Diantaranya penggunaan masker, sanitizer, kemudian physical distancing," ujar Emil. "Apalagi saat ini juga pemerintah mengimbau untuk melakukan aktivitas di rumah. Oleh karena itu, ia melihat jalur online akan menjadi salah satu cara untuk meningkatkan konsumsi," tandasnya. ${ }^{5}$

Dampak juga dirasakan oleh masyarakat Kabupaten Nganjuk, bukan hanya dampak pada kesehatan manusia saja melainkan juga kesehatan perekonomian. dengan adanya himbauan aktifitas dirumah atau physical distancing dari pemerintah maka hal ini sangat mempengaruhi laju perekonomian masyarakat kabupaten Nganjuk. Berdasarkan konferensi pers di Pendopo, Bupati Nganjuk juga menghimbau beberapa intruksi yang sudah dibuat, di antaranya yaitu :
a. Menghentikan sementara kegiatan Car Free Day
b. Menutup sementara Taman Kota yang ada di lingkungan Kabupaten Nganjuk
c. Menutup sementara tempat wisata, tempat hiburan dan kolam renang
d. Menghentikan sementara kegiatan Posyandu
e. Menunda Perjalanan keluar Daerah

Dari himbauan tersebut di atas maka hal ini sangat berdampak langsung pada pendapatan para pedagang kaki lima (PKL) yang ada di sekitar lokasi wisata, Banyaknya pengunjung di beberapa obyek wisata sebelum adanya pandemi covid-19 tentu mempengaruhi jumlah pendapatan para pedagang ketika adanya pandemi covid-19 seperti sekarang ini. Salah satu diantara sekian banyak Obyek wisata yang banyak diminati para pegunjung dan menjadi lokasi penelitian penulis yaitu :Air terjun sedudo, Taman Rekreasi Anjuk Ladang (TRAL), Gua Margo Tresno, Pemandian Air panas, dan Taman Pandan Wilis.

Dari observasi awal dengan sistem wawancara dengan Ibu Suparmi sebagai pedagang di wisata Taman Rekreasi Anjuk Ladang (TRAL) Kabupaten Nganjuk mengenai dampak pandemi covid-19, beliau mengatakan bahwa pendapatan yang diperoleh menurun drastis setiap harinya. Selain itu berdasarkan observasi di sekitar Alun-aun Nganjuk dengan Para pedagang yang biasanya berjualan di saat adanya kegiatan Car Free Day setiao hari minggu, mereka sangat mengeluhkan adanya intruksi penghentian sementara kegiatan tersebut karena dari intruksi yang dihimbau, menghasilkan dampak pada kesempatan kerja dan pendapatan rumah tangga mereka.

Berdasarkan uraian di atas, maka penulis tertarik untuk melakukan penelitian lebih lanjut mengenai "Dampak Pandemi Covid-19 Terhadap Perekonomian Dalam Tinjauan Sektor Perdagangan Dan Pariwisata Kabupaten Nganjuk (Deskriptif Analisis Sektor Perdagangan)

Berdasarkan latar belakang di atas dapat diambil permasalahan tentang pertumbuhan perekonomian masyarakat kabupaten Nganjuk sebelum wabah pandemi covid-19, perekonomian 
masyarakat kabupaten Nganjuk dalam masa Pandemi covid-19 dan dampak pandemi covid-19 terhadap kesempatan kerja dan pendapatan rumah tangga masyarakat kabupaten Nganjuk.

Adapun tujuan dari dilakukannya penelitian ini adalah untuk mengetahui pertumbuhan perekonomian masyarakat kabupaten Nganjuk sebelum wabah pandemi covid-19, perekonomian masyarakat kabupaten Nganjuk dalam masa Pandemi covid-19, dan juga dampak pandemi covid-19 terhadap kesempatan kerja dan pendapatan rumah tangga masyarakat kabupaten Nganjuk.

\section{METODE PENELITIAN}

Pendekatan dan jenis Penelitian yang digunakan pada penelitian ini adalah metode kualitatif. Metode kualitatif ini digunakan karena beberapa pertimbangan yaitu metode kualitatif lebih bisa dan mudah menyesuaikan apabila berhadapan dengan kenyataan ganda, metode ini menyajikan hakekat hubungan antara peneliti dan informan secara langsung dan metode ini lebih peka sehingga dapat menyesuaikan diri dan banyak penajaman pengaruh bersama terhadap pola-pola nilai yang dihadapi peneliti. ${ }^{6}$ Dalam pendekatan kualitatif, kehadiran peneliti sangat diperlukan untuk mengkaji lebih mendalam tentang rumusan masalah yang dibahas. kasi Penelitian

Peneliti memilih lokasi penelitian pada 6 Obyek tempat wisata di Kabupaten Nganjuk yang mempunyai daya tarik menonjol di Kabupaten Nganjuk yang berkaitan dengan dampak Pandemi Covid-19 pada sektor Pariwisata dan Perdagangan. Adapun sumber data di sini mengandalkan sumber data primer dan sekunder dengan menggunakan teknik pengumpulan data berupa observasi, wawancara, kuisioner dan juga dokumentasi. Sedangkan teknik analisis data menggunakan triangulasi sumber dan metode, diskusi teman sejawat dan juga perpanjangan keikutsertaan. Beberapa tahap penelitian yang penulis gunakan adalah tahap pra lapangan tahap pekerjaan lapangan, tahap analisis data dan juga tahap pelaporan.

\section{HASIL DAN PEMBAHASAN}

\section{Hasil penelitian \\ a. Pandemi Covid-19}

Pengertian covid-19

Pada 31 Desember 2019, WHO China Country Office melaporkan kasus pneumonia yang tidak diketahui etiologinya di Kota Wuhan, Provinsi Hubei, China. Pada tanggal 17 Januari 2020, China mengidentifikasi pneumonia yang tidak diketahui etiologinya tersebut sebagai jenis baru corona virus (novel coronavirus). Pada awal tahun 2020 NCP mulai menjadi pendemi global dan menjadi masalah kesehatan di beberapa negara di luar RRC. Berdasarkan World Health Organization (WHO) kasus kluster pneumonia dengan etiologi yang tidak jelas di Kota Wuhan telah menjadi permasalahan kesehatan di seluruh dunia. Penyebaran epidemi ini terus berkembang hingga akhirnya diketahui bahwa penyebab kluster pneumonia ini adalah Novel Coronavirus. Pandemi ini terus berkembang hingga adanya laporan kematian dan kasus-kasus baru di luar China. Pada tanggal 30 Januari 2020, WHO menetapkan COVID-19 sebagai Public Health Emergency of International Concern (PHEIC)/ Kedaruratan Kesehatan Masyarakat Yang Meresahkan Dunia (KKMMD). Pada tanggal 12 Februari 2020, WHO resmi menetapkan penyakit novel coronavirus pada manusia ini dengan sebutan Coronavirus Disease (COVID-19). COVID-19 disebabkan oleh SARS-COV2 yang termasuk dalam keluarga besar corona virus yang sama dengan penyebab SARS pada tahun 2003, hanya berbeda jenis virus nya. Gejalanya mirip dengan SARS, namun angka kematian SARS (9,6\%) lebih tinggi dibanding COVID-19 (saat ini kurang dari 5\%), walaupun jumlah kasus COVID-19 jauh lebih banyak dibanding

${ }^{6}$ Nik Haryanti, Metode Penelitian Ekonomi, Bandung: Manggu Makmur Tanjung Lestari, 2019, 127 
SARS. COVID-19 juga memiliki penyebaran yang lebih luas dan cepat ke beberapa negara dibanding SARS.

Penambahan jumlah kasus COVID-19 berlangsung cukup cepat dan sudah terjadi penyebaran keluar wilayah Wuhan dan negara lain. Sampai dengan 16 Februari 2020, secara global dilaporkan 51.857 kasus konfirmasi di 25 negara dengan 1.669 kematian (CFR 3,2\%). Rincian negara dan jumlah kasus sebagai berikut: China 51.174 kasus konfirmasi dengan 1.666 kematian, Jepang (53 kasus, 1 Kematian dan 355 kasus di cruise ship Pelabuhan Jepang), Thailand (34 kasus), Korea Selatan (29 kasus), Vietnam (16 kasus), Singapura (72kasus), Amerika Serikat (15kasus), Kamboja (1 kasus), Nepal (1 kasus), Perancis (12 kasus), Australia (15 kasus), Malaysia (22 ka- sus), Filipina (3 kasus, 1 kematian), Sri Lanka (1 kasus), Kanada (7 kasus), Jerman (16 kasus), Perancis (12 kasus), Italia (3 kasus), Rusia (2 kasus), United Kingdom (9 kasus), Belgia (1 kasus), Finlandia (1 kasus), Spanyol (2 kasus), Swedia (1 kasus), UEA (8 kasus), dan Mesir (1 Kasus).

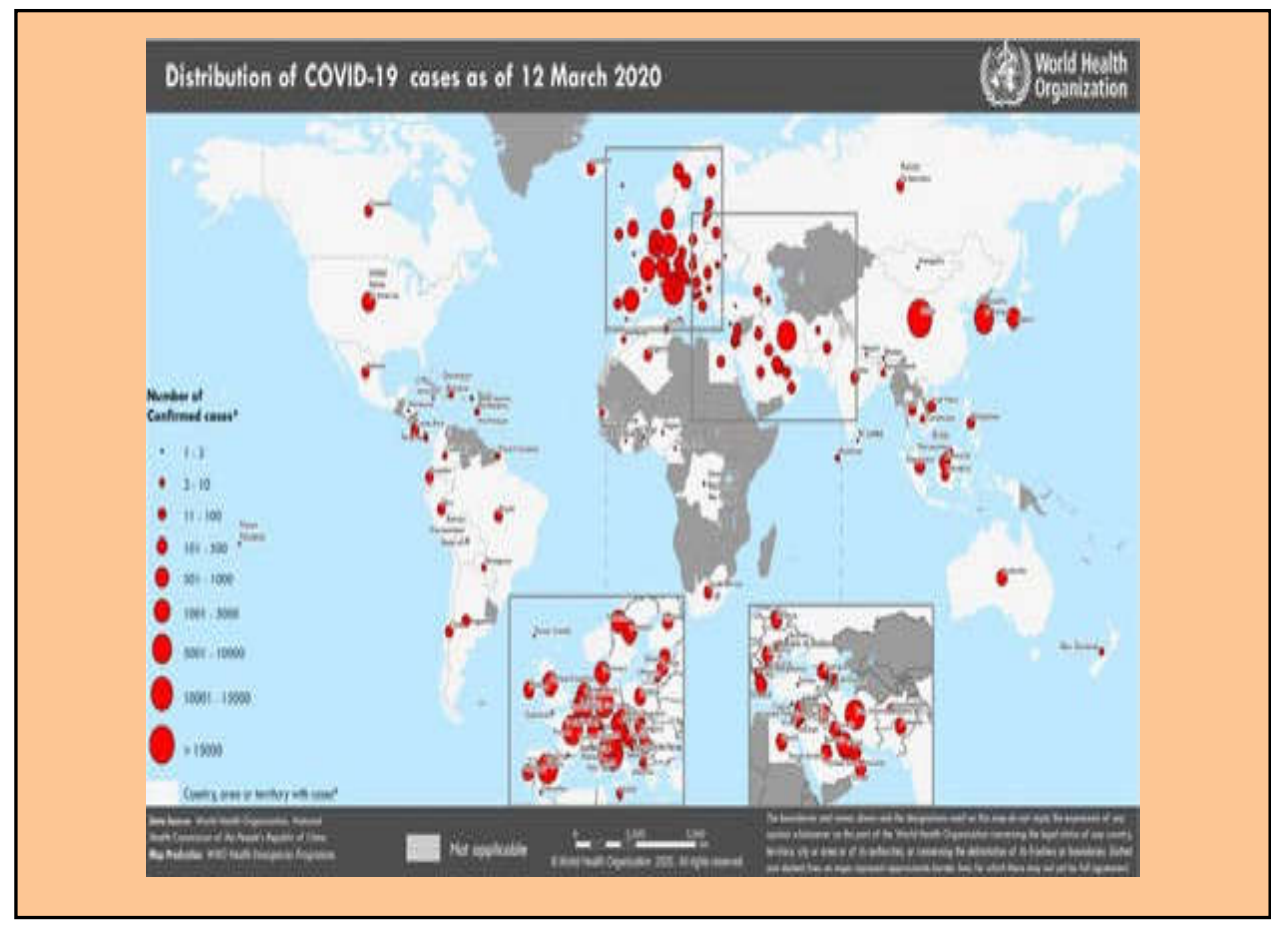

Gambar 1.1

Distribusi COVID-19 Per Tanggal 12 Maret 2020

Sumber : WHO

\section{b. $\quad$ Karakteristik covid-19}

\section{(1) Karakteristik Patogenik}

Corona virus merupakan keluarga besar virus yang menyebabkan penyakit pada manusia dan hewan. Pada manusia biasanya menyebabkan penyakit infeksi saluran pernapasan, mulai flu biasa hingga penyakit yang serius seperti Middle East Respiratory Syndrome (MERS) dan Sindrom Pernapasan Akut Berat/Severe Acute Respiratory Syndrome (SARS). Penyakit ini terutama menyebar di antara orang-orang melalui tetesan pernapasan dari batuk dan bersin. Virus ini dapat tetap bertahan hingga tiga hari dengan plastik dan stainless steel SARS CoV-2 dapat bertahan hingga tiga hari, atau dalam aerosol selama tiga jam. Virus ini juga telah ditemukan di feses, tetapi hingga Maret 2020 tidak diketahui apakah penularan melalui feses mungkin, dan risikonya diperkirakan rendah. 
Corona virus jenis baru yang ditemukan pada manusia sejak ke jadian luar biasa muncul di Wuhan China, pada Desember 2019, kemudian diberi nama Severe Acute Respiratory Syndrome Corona virus 2 (SARS- COV2), dan menyebabkan penyakit Corona virus Disease2019 (COVID-19). COVID-19 termasuk dalam genus dengan florelliptic dan sering berbentuk pleomorfik, dan berdiameter $60-140 \mathrm{~nm}$. Virus ini secara genetik sangat berbeda dari virus SARS-CoV dan MERS-CoV. Penelitian saat ini menunjukkan bahwa homologi antara COVID19 dan memiliki karakteristik DNA coronavirus pada kelelawar-SARS yaitu dengan kemiripan lebih dari 85\%. Ketika kultur pada vitro, COVID-19 dapat ditemukan dalam sel epitel pernapasan manusia setelah 96 jam. Sementara itu untuk mengisolasi dan mengkultur vero E6 dan Huh-7 garis sel dibutuhkan waktu sekitar 6 hari.

Paru-paru adalah organ yang paling terpengaruh oleh COVID-19, karena virus mengakses sel inang melalui enzim ACE2, yang paling melimpah di sel alveolar tipe II paru-paru. Virus ini menggunakan gliko protein permukaan khusus, yang disebut "spike", untuk terhubung ke ACE2 dan memasuki sel inang. Kepadatan ACE2 di setiap jaringan berkorelasi dengan tingkat keparahan penyakit di jaringan itu dan beberapa ahli berpendapat bahwa penurunan aktivitas ACE2 mungkin bersifat protektif. Dan seiring perkembangan penyakit alveolar, kegagalan pernapasan mungkin terjadi dan kematian mungkin terjadi.

\section{(2) Karakteristik Epidemilogi}

\section{(1) Orang dalam pemantauan (ODP)}

Seseorang yang mengalami gejala demam $\left(\geq 38^{\circ} \mathrm{C}\right)$ atau memiliki riwayat demam atau ISPA tanpa pneumonia. Selain itu seseorang yang memiliki riwayat perjalanan ke negara yang terjangkit pada 14 hari terakhir sebelum timbul gejala juga dikategorikan sebagai dalam pemantauan.

\section{(2) Pasien dalam pengawasan (PDP)}

Seseorang yang mengalami memiliki riwayat perjalanan ke negara yang terjangkit pada 14 hari terakhir sebelum timbul gejala-gejala COVID-19 dan seseorang yang mengalami gejala-gejala, antara lain: demam $\left(>38^{\circ} \mathrm{C}\right)$; batuk, pilek, dan radang tenggorokan, pneumonia ringan hingga berat berdasarkan gejala klinis dan/atau gambaran radiologis; serta pasien dengan gangguan sistem kekebalan tubuh (immuno compromised) karena gejala dan tanda menjadi tidak jelas.

Seseorang dengan demam $>38^{\circ} \mathrm{C}$ atau ada riwayat demam atau ISPA ringan sampai berat DAN pada 14 hari terakhir sebelum timbul gejala, memiliki salah satu dari paparan berikut: Riwayat kontak dengan kasus konfirmasi COVID-19, bekerja atau mengunjungi fasilitas kesehatan yang berhubungan dengan pasien konfirmasi COVID-19, memiliki riwayat per- jalanan ke Provinsi Hubei, memiliki sejarah kontak dengan orang yang memiliki riwayat perjalanan pada 14 hari terakhir ke Provinsi Hubei.

\section{(3) Karakteristik klinis}

Berdasarkan penyelidikan epidemiologi saat ini, masa inkubasi COVID-19 berkisar antara 1 hingga 14 hari, dan umumnya akan terjadi dalam 3 hingga 7 hari. Demam, kelelahan dan batuk kering dianggap sebagai manifestasi klinis utama. Gejala seperti hidung tersumbat, pilek, pharynx galgia, mialgia dan diare relatif jarang terjadi pada kasus yang parah, dispnea dan/atau hipoksemia biasanya terjadi setelah satu minggu setelah onset penyakit, dan yang lebih buruk dapat dengan cepat berkembang menjadi sindrom gangguan pernapasan akut, syok, septik, asidosis metabolik sulit untuk dikoreksi dan disfungsi perdarahan dan batuk serta kegagalan banyak organ, dll. Pasien dengan penyakit parah atau kritis mungkin mengalami demam sedang hingga rendah, atau tidak ada demam sama sekali. Kasus ringan hanya hadir dengan sedikit demam, kelelahan ringan dan sebagainya tanpa manifestasi pneumonia. Dari kasus yang ditangani saat ini, sebagian besar pasien memiliki prognosis yang baik. Orang tua dan orang- 
orang dengan penyakit kronis yang mendasari biasanya memiliki prognosis buruk sedangkan kasus dengan gejala yang relatif ringan sering terjadi pada anak-anak. ${ }^{7}$

\section{b. Perekonomian}

Sistem perekonomian adalah sistem yang digunakan oleh suatu daerah untuk mengalokasikan sumberdaya dan kemampuan yang di miliki baik untuk individu dan organisasi di negara tersebut. Perbedaan mendasar antara sistem perekonomian yang besar dengan berbagai sistem ekonomi lainnya adalah bagaimana sistem itu mengatur faktor produksinya. Dalam beberapa sistem, seorang individu boleh memiliki semua faktor produksi.

Sementara di perangkat lain semua faktor ini di pegang oleh pemerintah. Sebagian besar sistem moneter di dunia adalah di antara kedua hal ini sistem ekstrem. Selain unsur-unsur produksi, perangkat moneter juga dapat dikenali melalui cara program diatur produksi dan alokasi. Sebuah sistem ekonomi yang direncanakan (ekonomi direncanakan) hak pemerintah untuk mengatur faktor-faktor produksi dan alokasi produksi.

Subsistem, itulah sistem perekonomian yang terjadi pada awal peradaban manusia. Dengan karakteristik perekonomian subsistem, orang melakukan kegiatan ekonomi dalam hal produksi, hanya untuk memenuhi kebutuhan sendiri atau kelompoknya saja. Dengan kata lain pada saat itu orang belum terlalu berpikir untuk melakukan kegiatan ekonomi untuk pihak lain, apalagi demi keuntungan. Kalaupun orang tersebut harus berhubungan dengan orang lain untuk mendapatkan barang lain, sifatnya adalah barter, untuk kepentingan masing-masing pihak. Dengan semakin berkembangnya jumlah manusia beserta kebutuhannya, semakin dirasakan perlunya sistem perekonomian yang lebih teratur dan terencana.

\section{Perdagangan}

Pembangunan perdagangan merupakan salah satu kegiatan di bidang ekonomi yang mempunyai peran strategis dalam rangka pembangunan yang berwawasan nusantara. Sektor perdagangan berperan dalam mendukung kelancaran penyaluran arus barang dan jasa, memenuhi kebutuhan pokok rakyat, serta mendorong pembentukan harga yang wajar.

Pembangunan perdagangan sangat penting dalam upaya mempercepat pertumbuhan ekonomi dan pemerataan, dan memberikan sumbangan yang cukup berarti dalam penciptaan lapangan usaha serta perluasan kesempatan kerja dan peningkatan pendapatan. Kegiatan sektor perdagangan saling berkait dan saling menunjang dengan kegiatan sektor lainnya, seperti sektor produksi, yaitu pertanian, industri, dan pertambangan; sektor keuangan; sektor perhubungan dan telekomunikasi. Pembangunan perdagangan berperan penting pula dalam menciptakan dan mempertahankan stabilitas ekonomi dalam mengendalikan inflasi dan mengamankan neraca pembayaran.

\section{d. Pariwisata}

Pariwisata berasal dari bahasa sansekerta, sesungguhnya bukanlah berarti "tourisme" (bahasa Belanda) atau "tourism" (bahasa Inggris). Kata pariwisata menurut pengertian ini, sinonim dengan pengertian "tour". Pendapat ini berdasarkan pemikiran bahwa kata pariwisata terdiri dari dua suku kata yaitu pari dan wisata. Pari berarti banyak, berkali-kali, berputar-putar, lengkap. Wisata berarti perjalanan, berpergian yang dalam hal ini sinonim dengan kata trave. Maka dari itu pariwisata dapat diartikan sebagai perjalanan yang dilakukan berkali-kali atau berputar-putar, dari suatu tempat ke tempat lain. ${ }^{8}$ Dalam arti luas pariwisata adalah kegiatan rekreasi di luar domisili untuk melepaskan diri dari pekerjaan rutin atau mencari suasana lain. Sebagai suatu aktifitas, pariwisata telah menjadi bagian penting dari kebutuhan dasar masyarakat maju dan sebagian kecil masyarakat negara berkembang.

\footnotetext{
${ }^{7}$ Dr. Safrizal ZA, Msi, dkk, Pedoman umum menghadapi pandemi covid-19, Jakarta: Kementerian dalam negeri, 2020.

${ }^{8}$ Oka A. Yoeti, Pengantar Ilmu Pariwisata, (Bandung : Angkasa, 1996), 112.
} 
Pada hakikatnya berpariwisata adalah proses kepergian sementara dari seseorang atau lebih menuju tempat lain di luar tempat tinggalnya. Dorongan kepergiannya adalah karena berbagai kepentingan, baik karena kepentingan ekonomi, sosial kebudayaan, politik, agama, kesehatan maupun kepentingan lain seperti karena sekedar ingin tahu, menambah pengalaman ataupun untuk belajar. ${ }^{9}$ Pariwisata yang berasal dari kata wisata menurut Republik Indonesia No. 9 tahun 1990 tentang kepariwisataan mendefinisikan wisata sebagai kegiatan perjalanan yang dilakukan oleh seseorang atau sekelompok orang mengunjungi tempat tertentu dengan tujuan rekreasi, mengembangkan pribadi, atau mempelajari daya tarik wisata yang dikunjungi. ${ }^{10}$

Pariwisata merupakan salah satu sektor industri yang mampu menghasilkan perubahan ekonomi yang cepat dalam menyediakan lapangan kerja, meningkatkan pendapatan penghasilan pemerintah dan masyarakat. Standar hidup serta meningkatkan sektor-sektor produktifitas lainnya, untuk itu pariwisata harus disimpulkan dari cara penggunaan istilah tersebut.

Menurut Mill and Morrison, pariwisata merupakan sistem dari berbagai elemen yang tersusun seperti sarang laba-laba: "like a spider's web-touch one part of it and reverberations will be felt throughout. Fannel, menjelaskan bahwa pariwisata merupakan suatu sistem yang dapat dipandang sebagai : "... the interrelated system that includes tourists and the associated service that are provided and untilised (facilities, attractions, transportation, and accommodation) to aid in their movement". ${ }^{11}$

Berdasarkan pendapat beberapa ahli di atas dapat disimpulkan bahwa pariwisata adalah suatu perjalanan dari suatu tempat yang lain yang dilakukan oleh individu maupun kelompok yang bersifat sementara atau tidak untuk tinggal ditempat yang dikunjungi. ${ }^{12}$

\section{e. Kesempatan Kerja}

Kesempatan kerja merupakan salah satu indikator pembangunan ekonomi Ketika kesempatan kerja tinggi, pengangguran akan rendah dan ini akan berdampak pada naiknya pertumbuhan ekonomi suatu negara. Kesempatan kerja dapat dilihat dari banyaknya jumlah orang yang diterima bekerja dan tersedianya lapangan pekerjaan.

Pentingnya lapangan pekerjaan bagi masyarakat adalah sebagai sumber penghidupan untuk memenuhi kehidupannya sehari-hari. Lahan pekerjaan yang tersedia biasanya hanya terbatas, sehingga untuk mendapatkannya relatif semakin sulit. Hal Ini akan menimbulkan kesenjangan antaran permintaan dan penawaran tenaga kerja, sehingga berdampak pada pengangguran.

\section{f. Pendapatan Rumah Tangga}

Pendapatan rumah tangga adalah pendapatan yang diterima oleh rumah tangga bersangkutan baik yang berasal dari pendapatan kepala rumah tangga maupun pendapatan anggota-anggota rumah tangga. Pendapatan rumah tangga dapat berasal dari balas jasa faktor produksi tenaga kerja (upah dan gaji, keuntungan, bonus, dan lain lain), balas jasa kapital (bunga, bagi hasil, dan lain lain), dan pendapatan yang berasal dari pemberian pihak lain (transfer).

Hasil survei yang dihelat Saiful Mujani Research and Consulting (SMRC) menunjukkan, pendapatan rumah tangga anjlok 76 persen sejak kasus positif virus corona dikonfirmasi di

\footnotetext{
${ }^{9}$ Gamal Suwantoro, Dasar-dasar Pariwisata, (Yogyakarta: Andi, 2002), 3.

${ }^{10}$ Ismayanti, Pengantar Pariwisata, (Jakarta: PT Gramedia Widisarana, 2010), 169.

${ }^{11}$ Unggul Priyadi, Pariwisata Syariah Prospek dan Perkembangan, (Yogyakarta: UPP STIM YKPN, 2016), 29.

${ }^{12}$ Diana Setiati, Dampak keberadaan Objek Wisata Lava Tour terhadap keadaan sosial Ekonomi Masyarakat Desa Umbulharjo Cangkringan Sleman, (Universitas Sanata Dharma Yogyakarta, fakultar Keguruan dan Ilmu Pendidikan, 2015), 10.
} 
Indonesia pada Maret 2020. Survei dilakukan terhadap responden pada 18-20 Juni 2020. " Pendapatan rumah tangga pada awal Maret 2020 yang mengatakan turun itu meningkat secara drastis. Angkanya disekitar 76 persen. Sekarang ini 76 persen mengatakan pendapatan menurun dibandingkan sebelum wabah covid," ujar Direktur Media SMRC Ade Armando melalui webinar virtual, Kamis (25/6/2020). 7 dari 10 Masyarakat Ekonomi Bawah Mengalami Penurunan Pendapatan Responden yang menyatakan pendapatan rumah tangganya tetap sebesar 54 persen di awal Maret. Namun demikian, pada Juni ini, responden yang mengatakan pendapatan rumah mereka tetap hanya berkisar 19 persen. "Semenjak April, mula-mula 24 persen, sekarang turun jadi 19 persen," ucapnya. Ade menuturkan, pasca wabah virus corona berakhir, ada keoptimisan 46 persen responden yang mengatakan akan lebih baik. Sementara, yang berpendapat lebih buruk sebesar 23 persen. "Ternyata jawabannya cukup optimis 46 persen yang mengatakan akan lebih baik (pasca wabah virus corona). Yang mengatakan lebih buruk 23 persen, yang tidak mengatakan ada perubahan sekitar 22 persen. Jadi ada harapan bahwa kondisi ekonomi lebih baik kalau wabah Covid-19 berakhir," ujarnya.

Untuk kondisi keuangan rumah tangga pada tahun 2021, awal Maret 58 persen mengatakan optimis membaik. Lalu, memasuki Mei, pernyataan optimis itu justru menurun. "Kalau diperkirakan setahun ke depan keadaan ekonomi rumah tangga, pada bulan Maret, masih ada 58 persen yang mengatakan ekonomi rumah tangga setahun ke depan atau 2021 akan membaik. Tapi pada awal Mei itu turun hanya menjadi 27 persen," ujarnya. "Survei kita yang terakhir, orang mengatakan percaya bahwa keadaan ekonomi rumah tangga setahun ke depan membaik," sambung Ade. ${ }^{13}$

\section{PEMBAHASAN}

\section{Pertumbuhan Perekonomian Masyarakat Kabupaten Nganjuk Sebelum Wabah Pandemi Covid-19}

Berdasarkan temuan pada bab sebelumnya, bahwa pertumbuhan perekonomian masyarakat kabupaten nganjuk sebelum wabah pandemi covid-19 mengalami kelancaran dan tumbuh seperti biasanya, bahkan ada yang mengalami keningkatan karena adanya tempat-tempat wisata kuliner yang sekarang banyak sekali dijumpai yang bagus,unik dan menarik untuk dikunjungi.Oleh karena Itu peneliti ingin mewawancarai para pedagang dan masyarakat untuk mengetahui pertumbuhan perekonomian mereka sebelum wabah pandemi covid-19 tersebut. Berkenaan dengan hal tersebut Rumsiah (40) selaku pedagang kaki lima mengatakan sebelum adanya wabah virus corona, dagangan atau jualan saya cukup lumayan laris dan ramai pembeli. Setiap harinya, selama mulai membuka dagangan dari Pukul 08.00 WIB sampai dengan 02.00 WIB bisa meraih pendapatan omset Rp. 300400 ribu per-hari.

Dari hasil temuan wawancara dengan Sulvy, dia mengungkapkan bahwa Pendapatan saya lumayan dan dagangan saya selalu laku habis ketika saya menjajakan di acara car free day setiap hari minggu di alun-alun, karena banyak anak-anak muda yang berolahraga terkadang juga banyak yang hanya jalan-jalan untuk menikmati kuliner bersama keluarga, biasanya setiap minggu saya membawa 20-30 cup dengan per cup seharga Rp.5-10 ribu, itu sebelum adanya virus corona tetapi semenjak tidak dibukanya kembali acara car free day setiap hari minggu itu pendapatan saya hanya ada jika mendapatkan orderan online dari para pelanggan saya saja dan hal ini membuat penghasilan saya menurun, jadi saya harus giat melakukan promosi secara online.

Itulah berbagai jawaban dari hasil responden masyarakat mengenai pertumbuhan perekonomian mereka sebelum pandemi virus corona (covid-19).

Berdasarkan data pusat statistik Kabupaten Nganjuk Potensi perekonomian suatu wilayah di cerminkan oleh PDRB yang nilainya merupakan agregat nilai tambah yang dihasilkan oleh unit-unit

${ }^{13}$ Artikel ini telah tayang di Kompas.com dengan judul "Survei: Imbas Corona. 
produksi yang beroperasi di wilayah tersebut. PDRB juga merupakan salah satu indicator kesejahteraan penduduk dimana besaran PDRB menunjukkan pendapatan yang diterima oleh faktor produksi yang dimiliki oleh penduduk. Pertumbuhan PDRB merupakan salah satu tolok ukur perbaikan ekonomi suatu wilayah atau yang lebih familiar dikatakan sebagai pertumbuhan ekonomi wilayah tersebut. Pertumbuhan PDRB terbagi dua, yaitu pertumbuhan PDRB atas dasar harga berlaku (adhb) dan pertumbuhan PDRB atas dasar harga konstan (adhk). PDRB atas dasar harga berlaku menggambarkan produksi riil yang dipengaruhi oleh perubahan harga sehingga pertumbuhan PDRB ini sering dikatakan sebagai pertumbuhan semu karena di dalamnya masih mengandung besaran inflasi. PDRB atas dasar harga konstan menggambarkan pertumbuhan riil dari tahun ke tahun tanpa dipengaruhi perubahan harga/inflasi sehingga merupakan pertumbuhan riil atau pertumbuhan sesungguhnya, karena mengabaikan kenaikan harga barang dan jasa.

Selama sepuluh tahun terakhir, banyak perubahan yang terjadi pada tatanan global dan lokal yang sangat berpengaruh terhadap perekonomian. Salah satu bentuk adaptasi pencatatan statistik nasional adalah melakukan perubahan tahun dasar PDRB dari tahun 2000 ke 2010. Perubahan tahun dasar ini dilakukan seiring dengan mengadopsi rekomendasi PBB yang tertuang dalam 2008 System of National Accounts (SNA 2008). Manfaat perubahan tahun dasar antara lain : menginformasikan perekonomian regional yang terkini seperti pergeseran struktur dan pertumbuhan ekonomi; meningkatkan kualitas data PDRB; menjadikan data PDRB dapat diperbandingkan secara internasional. PDRB atas dasar harga berlaku Kabupaten Nganjuk pada tahun 2018 menunjukkan angka 24.879,374 miliar rupiah ada kenaikan sebesar 8,68 \% bila dibandingkan tahun 2017. Sedangkan PDRB atas dasar harga konstan sebesar 17.374,160 miliar rupiah, naik 5,38 \% dari tahun sebelumnya. PDRB Kabupaten Nganjuk tahun 2018, baik atas dasar harga berlaku maupun harga konstan nilai nominalnya mengalami peningkatan dibanding tahun-tahun sebelumnya. Hal ini menandakan bahwa aktivitas perekonomian di Kabupaten Nganjuk dari tahun ke tahun mengindikasikan kondisi yang menggembirakan. Pertumbuhan ekonomi Kabupaten Nganjuk tahun 2018 bila dibandingkan dengan tahun 2017, mengalami sedikit perlambatan yaitu dari 5,26\% pada tahun 2017 menjadi 5,39\% pada tahun 2018. peningkatan dibanding tahun-tahun sebelumnya. Hal ini menandakan bahwa aktivitas perekonomian di Kabupaten Nganjuk dari tahun ke tahun mengindikasikan kondisi yang menggembirakan. Tiga sektor ekonomi yang sangat dominan kontribusinya di Kabupaten Nganjuk pada tahun 2018, yaitu sektor : Pertanian, kehutanan, dan perikanan; Perdagangan besar dan eceran, reparasi mobil; dan Industri pengolahan. Kontribusi ketiga sektor tersebut masing-masing adalah 29,10\%, $20.20 \%$, dan $13.64 \%$. Kontribusi sektor lain : konstruksi (10.87 \%); administrasi pemerintahan (4.86 \%); informasi dan komunikasi (4.29\%); jasa pendidikan (3.73\%); jasa lainnya (2.80\%); jasa keuangan dan asuransi $(2.24 \%)$; pertambangan dan penggalian $(2.06 \%)$; penyediaan akomodasi dan makan minum $(1.93 \%)$; real estate $(1.64 \%)$; transportasi dan pergudangan (1.53\%); jasa kesehatan dan kegiatan sosial $(0.60 \%)$; jasa perusahaan $(0.33 \%)$; pengadaan air, pengelolaan sampah, limbah $(0.11 \%)$; pengadaan listrik dan gas $(0.05 \%)$

Ada sisi PDRB Pengeluaran dapat dilihat bahwa secara total, PDRB Kabupaten Nganjuk atas dasar harga Berlaku di tahun 2018 mengalami peningkatan volume ekonomi. Hal tersebut tercermin baik dari sisi produksi (supply side) maupun sisi permintaan akhir (demand side). Dari sisi produksi, pertumbuhan ekonomi tertinggi terjadi pada kategori Perdagangan Besar dan Eceran yang selalu tumbuh di atas 5\% setiap tahunnya. Dari sisi permintaan akhir, pertumbuhan ekonomi Kabupaten Nganjuk didominasi pertumbuhan komponen Pengeluaran Konsumsi Rumahtangga (PK-RT), yang menyumbang lebih dari separuh total PDRB. Peningkatan ini dipengaruhi baik oleh perubahan harga maupun perubahan volume. Peningkatan PDRB sisi produksi diikuti oleh peningkatan PDRB dari sisi permintaan akhir atau PDRB pengeluaran. Peningkatan PDRB menurut komponen pengeluaran Kabupaten Nganjuk pada periode 2013-2018 dapat dilihat pada grafik berikut ini: PDRB Kabupaten Nganjuk, sebagian besar digunakan untuk memenuhi kebutuhan konsumsi akhir rumahtangga (PKRT). Pengeluaran untuk akitvitas pembentukan modal (PMTB) juga mepunyai kontribusi yang besar, yakni $29,06 \%$. Meskipun komponen ekspor berkontribusi sebesar 46,9\%, namun di sisi lain komponen impor sebagai komponen pengurang dalam PDRB juga masih. 
PDRB Kabupaten Nganjuk, sebagian besar digunakan untuk memenuhi kebutuhan konsumsi akhir rumahtangga (PK-RT). Pengeluaran untuk akitvitas pembentukan modal (PMTB) juga mepunyai kontribusi yang besar, yakni 29,06 \%. Meskipun komponen ekspor berkontribusi sebesar 46,9\%, namun di sisi lain komponen impor sebagai komponen pengurang dalam PDRB juga masih berkontribusi relatif besar, yakni 59,6 \%. Hal ini mengindikasikan bahwa sebagian kebutuhan domestik masih harus dipenuhi oleh produk yang berasal dari luar wilayah atau bahkan luar daerah (impor). Kontribusi komponen konsumsi pemerintah (PK-P) terhadap PDRB Kabupaten Nganjuk sebesar 9,37\%. Hal tersebut menunjukkan peran pemerintah dalam menyerap PDRB tidak terlalu besar. Pada periode 2013-2018 perdagangan antar wilayah menunjukkan nilai ekspor yang lebih rendah dari nilai impor (dalam kondisi "defisit" atau merugi) yang artinya bahwa sebagian kebutuhan domestik masih harus dipenuhi oleh produk yang berasal dari luar wilayah Kabupaten Nganjuk. ${ }^{14}$

\section{Perekonomian Masyarakat Nganjuk dalam Masa Pandemi Covid-19.}

Perekonomian masyarakat Nganjuk dalam masa pandemi pasti berbeda dengan sebelum adanya pandemi covid-19. Terkait hal tersebut berdasarkan Bab sebelumnya, peneliti mewawancarai beberapa masyarakat. yaitu Suparmi (60),seorang pedagang di sekitar lokasi wisata Taman Rekresasi Anjuk Ladang (TRAL) mengatakan bahwa Semenjak ada virus corona ini pendapatan saya jelas menurun, gimana tidak menurun wisata Taman Rekreasi Anjuk Ladang di tutup dan tidak boleh berkerumun, jadi yang biasanya anak anak mudal ngopi juga agak sepi, malah saya sering tutup warung sekarang,ya dirumah saja.

Peneliti juga menanyakan Kepada Ady (30) seorang penjual bakso bakar di sekitar alun-alun Nganjuk mengenai kegiatannya selama wabah pandemi covid-19. Dia Mengatakan bahwa selama adanya corona ini penjualan menurun, apalagi waktu bulan puasa kemarin biasanya banyak orangorang yang ngabuburit dan beli bakso bakar buat cemilan mereka tapi bulan puasa tahun ini berkurang jauh, karena memang banyak orang yang takut keluar rumah karena virus ini, tapi saya tetap telaten tetap berjualan, kalau tidak berjualan walaupun pendapatan sekedarnya saya tidak dapat peghasilan apa-apa nantinya, ini saja hampir $75 \%$ pendapatan berkurang.

Rumsiah (40) selaku pedagang kaki lima (PKL) di alun-alun Nganjuk menambahkan bahwa Semenjak adanya wabah virus corona ini, hampir satu bulan lebih omset jualan saya turun drastis, dalam sehari saya Cuma meraup sekitar Rp 15 Ribu, kadang Cuma dapat Rp. 7 Ribu, meskipun sepi Pengunjung saya tetap membuka lapak saya, meskipun sekarang waktu berjualan juga di batasi oleh pemerintah kabupaten Nganjuk.

Berdasarkan data Pusat Statistik perekonomian kabupaten Nganjuk dalam masa pandemi covid-19 sebagai berikut:

a. Pada periode 2014-2019 perdagangan antar wilayah menunjukkan nilai ekspor yang lebih rendah dari nilai impor (dalam kondisi "defisit" atau merugi) yang artinya bahwa sebagian kebutuhan domestik masih harus dipenuhi oleh produk yang berasal dari luar wilayah kabupaten Nganjuk.

b. PDRB atas dasar harga berlaku Kabupaten Nganjuk pada tahun 2019 menunjukkan angka 26.664,613 miliar rupiah terdapat kenaikan sebesar 7,58 \% bila dibandingkan tahun 2018. Sedangkan PDRB atas dasar harga konstan sebesar 18.305,79 miliar rupiah, naik 5,32\% dari tahun sebelumnya.

c. PDRB Kabupaten Nganjuk, sebagian besar digunakan untuk memenuhi kebutuhan konsumsi akhir rumahtangga (PK-RT). Pengeluaran untuk akitvitas pembentukan modal (PMTB) juga mepunyai kontribusi yang besar, yakni 29,53 \%. Meskipun komponen ekspor berkontribusi sebesar 45,68 \%, namun di sisi lain komponen impor sebagai komponen pengurang dalam PDRB juga masih berkontribusi relatif besar.

${ }^{14}$ https://nganjukkab.bps.go.id/publication.html, diakses pada tanggal 5 juli 2020 
d. PDRB Kabupaten Nganjuk atas dasar harga Berlaku di tahun 2019 mengalami peningkatan volume ekonomi. Hal tersebut tercermin baik dari sisi produksi (supply side) maupun sisi permintaan akhir (demand side).

Dari sisi produksi, pertumbuhan ekonomi tertinggi terjadi pada kategori Perdagangan Besar dan Eceran yang selalu tumbuh di atas 5\% setiap tahunnya. Dari sisi permintaan akhir, pertumbuhan ekonomi Kabupaten Nganjuk didominasi pertumbuhan komponen Pengeluaran Konsumsi Rumahtangga (PK-RT), yang menyumbang lebih dari separuh total PDRB.

\section{Dampak Pandemi Covid-19 terhadap Kesempatan Kerja dan Pendapatan Rumah Tangga Masyarakat Kabupaten Nganjuk.}

Covid-19 juga berdampak pada kehidupan masyarakat. Beberapa dampak yang dialami oleh masyarakat adalah penurunan pendapatan, kesulitan memenuhi kehidupan sehari-hari termasuk bahan pokok, mengalami stres, dan adanya perubahan dalam berkomunikasi dengan orang lain. Beberapa responden menyatakan bahwa dengan adanya pembatasan kegiatan, beberapa bahan pokok menjadi sulit diperoleh di pasar. Hal ini disebabkan karena adanya larangan bagi penjual yang datang dari luar desa atau daerah. Terkait hal ini berdasarkan bab sebelumnya penulis juga mewawancarai beberapa nara sumber.

Yaitu wawan (45) selaku juru parkir di lokasi wisata Taman Pandan Wilis (TPW). Beliau mengatakan bahwa Taman Pandan Wilis ini gak pernah sepi, rame terus anak-anak muda dan orang tua beserta anaknya, tapi karena ada intruksi tempat wisata disuruh tutup dulu jadinya sekarang saya jadi pengangguran sementara waktu.Untuk makan sehari-hari dari anak dan bantuan pemerintah. Dampak juga dirasakan oleh Tya (27) seorang penjual lumpia di wisata air panas jatikalen yang biasanya ramai pembeli dari datangnya pengunjung wisata, dia berkata Karena adanya virus corona ini saya harus kreatif dan putar otak untuk memuhi kebutuhan sehari-hari, karena pendapatan rumah tangga kami (beserta suami) menurun, apalagi suami sopir grap. Sekarang grap juga sepi gak boleh order penumpang bolehnya makanan. Jadi untuk mengatasi keterpurukan karena covid-19 ini saya pidah berjualan di area alun-alun Nganjuk. walaupun alun-alun tutup tapi setidaknya jalanan kota masih ada yang lewat dan satu, dua ,tiga pembeli masih adalah lumayan untuk nambah-nambah penghasilan.

Berdasarkan Badan pusat statistik terlihat bahwa jumlah penduduk usia kerja di Kabupaten Nganjuk terus bertambah pada periode 2013-2019 sebagai dampak pertumbuhan penduduk yang masih positif. Yang menarik, jumlah laki-laki yang bekerja turun, sementara jumlah perempuan yang bekerja naik tipis. Apabila dilihat keseluruhan, jumlah pekerja di Kabupaten Nganjuk pada tahun 2019 berkurang sekitar 9 ribu jiwa.

Jumlah penganggur tahun 2019 bertambah 3 ribu jiwa, dimana penganggur laki-laki dan perempuan bertambah masing-masing sebesar 1500 jiwa. Jumlah penduduk yang bersekolah bertambah 7 ribu jiwa sebagai dampak pelaksanaan program wajib belajar dan pertumbuhan ekonomi. Fenomena lain, jumlah pengurus rumahtangga baik laki-laki dan perempuan berkurang sekitar 4 ribuan.

Kondisi ketenagakerjaan Kabupaten Nganjuk selama tahun 2019 juga menunjukkan hal-hal yang unik. Pertama, Jumlah angkatan kerja bertambah sekitar 45 ribu jiwa. Kedua jumlah penduduk yang bekerja juga bertambah sekitar 43 ribu jiwa. Akan tetapi, Ketiga, Tingkat Partisipasi Angkatan Kerja (TPAK), yang menggambarkan pasokan tenaga kerja, menurun dibanding tahun sebelumnya, terutama pada penduduk laki-laki. Sementara itu, indikator ketenagakerjaan yang paling dikenal, tingkat pengangguran terbuka (TPT), meningkat dibanding tahun 2018. TPT laki-laki dan perempuan hampir sama, hal ini mungkin bisa diartikan bahwa kesetaraan kesempatan bekerja bagi laki-laki dan perempuan sudah seimbang. Berbeda dengan kondisi Indonesia secara keseluruhan, ternyata TPT pendidikan tinggi (Diploma/Universitas) di Kabupaten Nganjuk paling rendah. Secara teori, lulusan pendidikan tinggi ini lebih mudah mencari pasar kerja karena menerima informasi lebih dulu dibanding lulusan lainnya. Di samping itu, lulusan pendidikan tinggi juga cenderung menerima on-the- 
job-training sehingga mereka tidak mudah keluar dari pasar kerja. Sementara itu, TPT lulusan SMK relatif lebih rendah dan berada pada urutan kedua. TPT paling tinggi berada pada lulusan SMA Umum. Secara ringkas dapat dikatakan bahwa sektor perekonomian Kabupaten Nganjuk memang masih bertumpu pada sektor pertanian.

Kesempatan kerja yang berkurang atau menurun juga memberikan dampak pada pendapatan rumah tangga masyarakat kabupaten Nganjuk. Berdasarkan data sebanyak 41.141 kepala keluarga (KK) di Kabupaten Nganjuk akan mendapatkan dana bantuan jaring pengaman sosial dampak Covid19 dari Pemerintah Pusat dan Pemprov Jatim.

Jumlah tersebut masih akan ditambah sebanyak 22.200 KK yang juga akan mendapat jaring pengaman sosial bersumber dari APBD Kabupaten Nganjuk. Bupati Nganjuk, Novi Rahman Hidayat mengatakan, jumlah penerima jaring pengaman sosial dampak Covid-19 dari APBD Kabupaten Nganjuk dipastikan masih akan ditambah seiring dengan selesainya refocusing anggaran yang kini terus dilakukan. "Kami harap warga kurang mampu terdampak Covid-19 dengan adanya bantuan jaring pengaman baik dari Pemerintah Pusat dan Pemprov Jatim serta dari APBD Kabupaten Nganjuk bisa terbantu perekonomiannya," kata Novi Rahman Hidhayat, Kamis (23/4/2020).

Jadi bantuan jaminan pengaman sosial ini ditujukan untuk warga dampak covid-19 yang belum mendapatkan program bantuan apapun dari Pemerintah. Sementara Ketua DPRD Kabupaten Nganjuk, Tatit Heru Tjahjono mengatakan, pihaknya mengharapkan adanya realsiasi bantuan kepada warga terdampak covid-19 di Kabupaten Nganjuk secepatnya.

Ini dikarenakan kondisi warga kurang mampu Kabupaten Nganjuk akibat virus corona sekarang ini cukup memprihatinkan, Menurut peneliti, dari hasil pengamatan peneliti sendiri, pertumbuhan perekonomian dari sebelum adanya pandemi covid-19 hingga kini serta dampak yang diakibatkan mengenai kesempatan kerja dan pendapatan rumah tangga Kabupaten Nganjuk memang mengalami penurunan, namun pemerintah kabupaten Nganjuk berusaha untuk menstabilkan perekonomian dengan memberikan bantuan kepada masyarakat yang terdampak covid-19 serta membuka persiapan adab kebiasaan baru agar masyarakat tetap produktif namun tetap memperhatikan protokol kesehatan.

\section{KESIMPULAN}

Dari uraian di atas, maka peneliti akan menyimpulkan sebagai berikut:

\section{Pertumbuhan Perekonomian masyarakat kabupaten Nganjuk sebelum wabah pandmi covid-19}

Berdasarkan hasil temuan pada bab sebelumnya, bahwa pertumbuhan perekonomian masyarakat kabupaten nganjuk sebelum wabah covid-19 dirasakan stabil, hal ini dilihat dari pendapatan para pedagang yang stabil cenderung meningkat. Berdasarkan data pusat statistik aktivitas perekonomian di Kabupaten Nganjuk dari tahun ke tahun mengindikasikan kondisi yang menggembirakan. Pertumbuhan ekonomi Kabupaten Nganjuk tahun 2018 bila dibandingkan dengan tahun 2017, yaitu dari 5,26 \% pada tahun 2017 menjadi 5,39\% pada tahun 2018. peningkatan dibanding tahun-tahun sebelumnya.

\section{Perekonomian masyarakat kabupaten nganjuk dalam masa pandemi covid-19}

Pada awal adanya pandemi PDRB atas dasar harga berlaku Kabupaten Nganjuk mencatat pada tahun 2019 menunjukkan angka 26.664,613 miliar rupiah terdapat kenaikan sebesar $7,58 \%$ bila dibandingkan tahun 2018. Sedangkan PDRB atas dasar harga konstan sebesar $18.305,79$ miliar rupiah, naik 5,32 \% dari tahun sebelumnya. Dalam masa melewati pandemi covid-19 masyarakat nganjuk mengalami dampak perekonomian yang cukup siknikfikan dari pada bulan-bulan sebelumnya atau sebelum adanya virus corona hal ini di rasakan oleh banyaknya pedagang yang mengalami penurunan omset sekitar $75 \%$.

Dampak pandemi covid-19 terhadap kesempatan kerja dan pendapatan rumah tangga masyarakat kabupaten nganjuk. 
Berdasarkan Badan pusat statistik Jumlah penganggur tahun 2019 bertambah 3 ribu jiwa, dimana pengangguran laki-laki dan perempuan bertambah masing-masing sebesar 1500 jiwa. Jumlah penduduk yang bersekolah bertambah 7 ribu jiwa sebagai dampak pelaksanaan program wajib belajar dan pertumbuhan ekonomi.

Kesempatan kerja yang berkurang atau menurun juga memberikan dampak pada pendapatan rumah tangga masyarakat kabupaten Nganjuk. Dan untuk menyikapi adanya dampak pandemi covid-19 Berdasarkan data sebanyak 41.141 kepala keluarga (KK) di Kabupaten Nganjuk akan mendapatkan dana bantuan jaring pengaman sosial dampak Covid-19 dari Pemerintah Pusat dan Pemprov Jatim. Jumlah tersebut masih akan ditambah sebanyak 22.200 KK yang juga akan mendapat jaring pengaman sosial bersumber dari APBD Kabupaten Nganjuk.

\section{UCAPAN TERIMA KASIH}

Untuk dapat menyelesaikan penelitian ini, penulis mendapatkan berbagai bantuan dari beberapa pihak. Oleh karena itu penulis berkewajiban menyampaikan rasa terima kasih sedalam-dalamnya, terutama kepada: Rektor Institut Agama Islam Pangeran Diponegoro (IAI PD) Nganjuk yang telah memberikan izin kepada penulis untuk dapat menyelesaikan studi akhir. Dekan Fakultas Syariah dan Ekonomi Islam, yang telah memberikan izin dan pengarahan pada peneliti.

\section{DAFTAR RUJUKAN}

Diana Setiati, Dampak keberadaan Objek Wisata Lava Tour terhadap keadaan sosial Ekonomi Masyarakat Desa Umbulharjo Cangkringan Sleman, (Universitas Sanata Dharma Yogyakarta, fakultar Keguruan dan Ilmu Pendidikan, 2015), 10.

Dr. Safrizal ZA, Msi, dkk, Pedoman umum menghadapi pandemi covid-19, Jakarta: Kementerian dalam negeri, 2020.

Gamal Suwantoro, Dasar-dasar Pariwisata, (Yogyakarta: Andi, 2002).

https://finance.detik.com/berita-ekonomi-bisnis/d-4902563/ di-depan-dpr-mentan-ngeluh-ekspor-imporpangan-terganggu-corona, diakses 13 April 2020

https://katadata.co.id/ berita/2020/02/07/dampak-virus-corona-sp-pangkas-proyeksi-pertumbuhan-ekonomitiongkok, diakses 13 april 2020.

https://katadata.co.id/ telaah/2020/02/05/virus-corona-tekan-ekonomi-tiongkok-dunia-waspadaiperlambatan-global, diakses 13 April 2020

https://nganjukkab.bps.go.id/publication.html,

https://www.liputan6.com/bisnis/read/4219047/jurus-pemprov-jatim-tekan-dampak-covid-19-keperekonomian-wilayahnya.

https://www.merdeka.com/ uang/porak-poranda-ekonomi-china-akibat-wabah-corona-banyak-usahaterancam-bangkrut. html, diakses 12 April 2020

Ismayanti, Pengantar Pariwisata, (Jakarta: PT Gramedia Widisarana, 2010).

Nik Haryanti, Metode Penelitian Ekonomi, Bandung: Manggu Makmur Tanjung Lestari, 2019.

Oka A. Yoeti, Pengantar Ilmu Pariwisata, (bandung: Angkasa, 1996).

Unggul Priyadi, Pariwisata Syariah Prospek dan Perkembangan, (Yogyakarta: UPP STIM YKPN, 2016), 29. 